http://dx.doi.org/10.11646/phytotaxa.156.4.3

\title{
Psilocybe chuxiongensis, a new bluing species from subtropical China
}

\author{
TAO MA ${ }^{1}$, YING FENG ${ }^{1}$, XIAO-FEI LIN ${ }^{1}$, SAMANTHA C. KARUNARATHNA ${ }^{2}$, WEI-FENG DING ${ }^{1} \&$ KEVIN $^{2}$ \\ D. HYDE ${ }^{1,2^{*}}$ \\ ${ }^{I}$ The Research Institute of Resource Insects, Chinese Academy of Forestry, Kunming, Yunnan 650224, China \\ *email:kdhyde3@gmail.com \\ ${ }^{2}$ Institute of Excellence in Fungal Research, and School of Science, Mae Fah Luang University 333 Moo l, Tasud, Muang, Chiang Rai \\ 57100, Thailand
}

\begin{abstract}
A new bluing species of Psilocybe in sect. Caerulescentes is described from subtropical China. It is closely related to $P$. cubensis but can be differentiated by the lack of an annulus and the buff-yellow to yellowish brown, hemispheric to hemispheric-convex pileus without an umbo or papilla. Phylogenetic analyses of ITS, nrLSU and combined $r p b 2-t e f 1-\alpha$ datasets using maximum parsimony and Bayesian inference also indicate its uniqueness. The relationship with $P$. cubensis is well-supported by molecular data with high support values in all three datasets. Psilocybe chuxiongensis sp. nov. is presented here with a description, photographs, and line drawings.
\end{abstract}

Key words: hallucinogenic, ITS, molecular phylogeny, nrLSU, rpb2, Strophariaceae, tefl- $\alpha$

\section{Introduction}

The genus Psilocybe (Fr.) P. Kumm. (Basidiomycota, Agaricales, Strophariaceae) is well-known for its hallucinogenic species, which have aroused the interests of many mycologists (Guzmán 1983, 2009, Guzmán et al. 1998, Andersson et al. 2008). There have been considerable taxonomic and systematic studies on this group over the last six decades (Heim \& Wasson 1958, Singer \& Smith 1958, Guzmán 1983, 1995, 2009, Singer 1986, Stamets 1996, Noordeloos 1999, 2011, Moncalvo et al. 2002, Matheny et al. 2006, Redhead et al. 2007, Ramírez-Cruz et al. 2013). More than 150 hallucinogenic species of Psilocybe are known worldwide (Guzmán 2005, 2009), with about 25 Asiatic species of bluing Psilocybe recorded mainly from tropical or subtropical forests in south and southeast Asia (Guzmán 2009, Guzmán \& Yang 2010, Guzmán et al. 2012). However, with the exception of $P$. taiwanensis Zhu L. Yang \& Guzmán in Guzmán and Yang (2010: 185) from Taiwan, and P. venenata (S. Imai 1938: 270) Imazeki \& Hongo (1957: 146), mentioned in Guzmán et al. (1998), Chinese species are poorly known in the world outside China.

Twenty Psilocybe species have previously been reported from China (Teng 1963, Tai 1979, Anonym 1983, Li 1991, Bi et al. 1994, Mao 2000, Lin et al. 2005, He et al. 2007, Yuan \& Sun 2007, Bau \& Sarentoya 2009, Guzmán and Yang 2010), but only 14 species now belong to Psilocybe. Psilocybe mongolica Sarentoya \& T. Bau (2009: 28) and $P$. taiwanensis were described from China, while many of the 20 species are incorrectly identified, in doubt or excluded in Bau \& Sarentoya (2009) or modern treatments. Among the 14 Chinese species, P. crobula (Fr. 1838: 199) Singer (1962: 70), P. coprophila (Bull. 1793: 423) P. Kumm. (1871: 71), P. merdaria (Fr. 1821: 291) Ricken (1912: 251), and P. mongolica are non-blueing (non-hallucinogenic) species, which were moved to Deconica (W.G. Sm.) P. Karst. based on molecular analysis (Moncalvo et al. 2002, Matheny et al. 2006, Norvell 2009). Nine species namely P. argentipes K. Yokoy (1976: 349), P. baeocystis Singer \& A.H. Smith (1958: 141), P. cubensis (Earle 1906: 240) Singer (1948: 37), P. fasciata Hongo (1957: 144), P. pelliculosa (A.H. Sm.1937: 58) Singer \& A.H. Smith (1958: 280), P. taiwanensis, P. venenata, P. wayanadensis K.A. Thomas, Manimohan \& Guzmán (2002: $198)$ and P. yungensis Singer \& A.H. Smith (1958: 142) are bluing species. Considering there are more than 200 species of Psilocybe (Guzmán 1983, 1995) known worldwide, and China has a diverse macrofungi (Yang 2005, 


\section{Acknowledgments}

Financial support was provided by the Grant for Essential Scientific Research of Chinese National Nonprofit Institute (no. riricaf2011003z and Riri200707M). Special thanks to Prof. Zhu-Liang Yang for his guidance in taxonomic study and valuable comment of the manuscript. Many thanks to Prof. Gastón Guzmán for his guidance in field exploration and kindly providing his monograph and some important papers. Chen-Ye Wang, Hang Chen, Xi-Hui Du, Jian-Kui Lui and Jing Luo are warmly thanked for their help of molecular data analysis. We would also thank Hui Yang and Yan-Ming Zhang for their assistant in field explorations, and Nian-Kai Zeng and Lan Wang for kindly providing related literature.

\section{References}

Andersson, C., Kristinsson, J. \& Gry, J. (2008) Occurrence and use of hallucinogenic mushrooms containing psilocybin alkaloids. TemaNord 2008:606, Nordic Council of Ministers, Copenhagen, $121 \mathrm{pp}$.

Anonym (1983) Fungi of Xizang. Science Press, Beijing, 226 pp.

Barnes, C.W., Ordonez, M.E. \& Salazar, A. (2012) Identification and evaluation of some fungi with cellulase activity isolated in Ecuador. Revista Ecuatoriana De Medicina y Ciencias Biológicas 33: 65-81.

Bas, C., Kuyper, T.W., Noordeloos, M.E. \& Vellinga, E.C. (1988) Flora Agaricina Neerlandica : Critical monographs on the families of agarics and boleti occurring in the Netherlands vol. 1. A. A. Balkema, Rotterdam, $182 \mathrm{pp}$.

Bau, T. \& Sarentoya (2009) Strophariaceae of China (IV) Psilocybe. Journal of Fungal Research 1 (7): 14-36.

Bi, Z.S., Zheng, G.Y. \& Li, T.H. (1994) Macrofungus Flora of Guangdong Province. Guangdong Science and Technology Press, Guangzhou, 879pp.

Binder, M., Larsson, K.H., Matheny, P.B. \& Hibbett, D.S. (2010) Amylocorticiales ord. nov. and Jaapiales ord. nov.: early diverging clades of Agaricomycetidae dominated by corticioid forms. Mycologia 102 (4): 865-880. http://dx.doi.org/10.3852/09-288

Borovička, J., Noordeloos, M.E., Gryndler, M. \& Oborník, M. (2011) Molecular phylogeny of Psilocybe cyanescens complex in Europe, with reference to the position of the secotioid Weraroa novae-zelandiae. Mycological Progress 10 (2): $149-155$. http://dx.doi.org/10.1007/s11557-010-0684-3

Borovička, J., Rockefeller, A. \& Werner, P.G. (2012) Psilocybe allenii-a new bluing species from the Pacific Coast, USA. Czech Mycology 2 (64): 181-195.

Bulliard, J.B.F. (1793) Histoire des champignons de la France, 2. Leblanc, Paris, 2:373-508.

Dai, Y.C. \& Zhuang, J.Y. (2010) Numbers of fungal species hitherto known in China. Mycosystema 6 (29): 625-628.

Earle, F.S.(1906) Algunos hongos cubanos. Información Anual Estación Central Agronomica Cuba 1: $225-242$.

Fries, E.M.(1815) Observationes mycologicae. Gerh. Bonnier, Copenhagen, 230pp.

Fries, E.M.(1821) Systema Mycologicum. Lund, 520pp.

Fries, E.M.(1838) Epicrisis systematis mycologici. Uppsala, 612pp.

Guzmán, G. (1983) The genus Psilocybe. Beih.Nova Hedwigia 74, Cramer, Vaduz, 439 pp.

Guzmán, G. (1995) Supplement to the monograph of the genus Psilocybe. In: Petrini, O., Horak, E. (Eds.), Taxonomic monographs of Agaricales, vol. Bibliotheca Mycol 159. Cramer, Berlin, pp. 91-141.

Guzmán, G. (2005) Species diversity of the genus Psilocybe (Basidiomycotina, Agaricales, Strophriaceae) in the world mycobiota, with special attention to hallucinogenic properties. International Journal of Medicinal Mushroom 7: 305-331. http://dx.doi.org/10.1615/intjmedmushr.v7.i12.280

Guzmán, G. (2009) The hallucinogenic mushrooms: diversity, traditions, use and abuse with special reference to the genus Psilocybe. In: Misha, J.K., Deshmukh, S.K. (Eds.), Fungi from different environments. Science Publishers, Enfield(NH), pp. 256-277.

Guzmán, G. \& Vergeer, P. (1978) Index of taxa in the genus Psilocybe. Mycotaxon 6 (3): 464-476.

Guzmán, G. \& Yang, Z.L. (2010) A new species of a bluing Psilocybe from Asia (Basidiomycota, Agaricales, Strophariaceae). Sydowia 62 (2): 185-189.

Guzmán, G., Allen, J.W. \& Gartz, J. (1998) A worldwide geographical distribution of the neurotropic fungi, an analysis and discussion. Annali del Museo civico di Rovereto 14: 189-280.

Guzmán, G., Guillén, F.R., Hyde, K.D. \& Karunarathna, S.C. (2012) Psilocybe s.s. in Thailand: four new species and a review of previously recorded species. Mycotaxon 119: 65-81. http://dx.doi.org/10.5248/119.65

Hall, T.A. (1999) BioEdit: a user-friendly biological sequence alignment editor and analysis program for Windows 95/98/NT. Nucleic Acids Symposium Series 41: 95-98.

He, S.H. \& Dai, Y.C. (2012) Taxonomy and phylogeny of Hymenochaete and allied genera of Hymenochaetaceae (Basidiomycota) in China. Fungal Diversity 56 (1): 77-93. http://dx.doi.org/10.1007/s13225-012-0174-9 
He, X.S., Hou, D.B., He, P.X. \& Zhu, W.K. (2007) The biological characteristics of wild mushroom and its cultivation techniques. Chinese Light Industry Press, Beijing, 209 pp.

Heim, R. \& Wasson, R.G. (1958) Hallucinogenic mushrooms of Mexico. Archives Du Muséum National d'Histoire Naturelle, 7e Série, Tome VI, Éditions du Muséum, Paris.

Hongo, T. (1957) Notes on Japanese larger fungi (10). Journal of Japanese Botany 32: 141-146.

Huelsenbeck, J.P. \& Ronquist, F. (2005) Bayesian analysis of molecular evolution using MrBayes. In: Nielsen, R. (ed) Statistical Methods in Molecular Evolution. Springer, New York, pp 183-232.

Hujslová, M., Kubátová, A., ChudíčKová, M. \& Kolařík, M. (2010) Diversity of fungal communities in saline and acidic soils in the Soos National Natural Reserve, Czech Republic. Mycological Progress 9: 1-15. http://dx.doi.org/10.1007/s11557-009-0611-7

Imai, S. (1938) Studies on the Agaricaceae of Hokkaido.1. Journal of the Faculty of Agriculture of the Hokkaido Imperial University 43:1-378.

Kauserud, H. \& Schumacher, T. (2001) Outcrossing or inbreeding: DNA markers provide evidence for type of reproductive mode in Phellinus nigrolimitatus (Basidiomycota). Mycological Research 105 (6): 676-683. http://dx.doi.org/10.1017/s0953756201004191

Kornerup, A. \& Wanscher, J.H. (1981) Taschenlexikon der Farben. 3.Aufl. Muster-Schmidt Verlag, Göttingen, 242 pp.

Kummer, P.(1871) Der Führer in die Pilzkunde. C. Luppe, Zerbst, 146pp.

Largent, D., Johnson, D. \& Watling, R. (1977) How to identify mushrooms to genus III: microscopic features. Mad River Press, Eureka, CA, 148 pp.

Li, R.G. (1991) Fungi flora of Jinlin Province.Vol.I. Northeast Teacher's University Press, Changchun, 528 pp.

Lin, X.M., Li, Z.Q. \& Hou, J. (2004) The Diversity of Macrofungi in China. China Agriculture Press, Beijing, 295 pp.

Liu, P.G., Wang, X.H., Yu, F.Q., Chen, J., Tian, X.F., Deng, X.J., Xie, X.D. \& Shi, X.F. (2009) Fungous kingdom: Yunnan of China and her ectomycorrhizal macrofungal species diversity. Acta Botanica Yunanica Suppl. 16: 15-20.

Liu, Y.L., Whelen, S. \& Hall, B.D. (1999) Phylogenetic relationships among ascomycetes: evidence from an RNA polymerase II subunit. Molecular Biology and Evolution 16 (12): 1799-1808.

http://dx.doi.org/10.1093/oxfordjournals.molbev.a026092

Mao, X.L. (2000) The macrofungi in China. Henan Science and Technology Press, Zhengzhou, 719 pp.

Maruyama, T., Kawahara, N., Yokoyama, K., Makino, Y., Fukiharu, T. \& Goda, Y. (2006) Phylogenetic relationship of psychoactive fungi based on rRNA gene for a large subunit and their identification using the TaqMan assay (II). Forensic Science International 163: 51-58.

http://dx.doi.org/10.1016/j.forsciint.2004.10.028

Maruyama, T., Yokoyama, K., Makino, Y. \& Goda, Y. (2003) Phylogenetic relationship of psychoactive fungi based on the rRNA gene for a large subunit and their identification using the TaqMan assay. Chemical \& Pharmaceutical Bulletin (Tokyo) 51 (6): 710-714.

http://dx.doi.org/10.1248/cpb.51.710

Massee, G.E. (1906) Fungi exotici, IV. Bulletin of Miscellaneous Informations of the Royal Botanical Gardens Kew 1906: 9194. http://dx.doi.org/10.2307/4113276

Matheny, P.B., Curtis, J.M., Hofstetter, V., Aime, M.C., Moncalvo, J.M., Ge, Z.W., Yang, Z.L., Slot, J.C., Ammirati, J. F., Baroni, T.J., Bougher, N.L., Hughes, K.W., Lodge, D.J., Kerrigan, R.W., Seidl, M.T., Aanen, D.K., DeNitis, M., Daniele, G.M., Desjardin, D.E., Kropp, B.R., Norvell, L.L., Parker, A., Vellinga, E.C., Vilgalys, R. \& Hibbett, D.S. (2006) Major clades of Agaricales: a multilocus phylogenetic overview. Mycologia 98 (6): 982-995. http://dx.doi.org/10.3852/mycologia.98.6.982

Matheny, P.B., Wang, Z., Binder, M., Curtis, J.M., Lim, Y.W., Nilsson, R.H., Hughes, K.W., Hofstetter, V., Ammirati, J. F., Schoch, C.L., Langer, E., Langer, G., McLaughlin, D.J., Wilson, A.W., Frøslev, T., Ge, Z.W., Kerrigan, R.W., Slot, J.C., Yang, Z.L., Baroni, T.J., Fischer, M., Hosaka, K., Matsuura, K., Seidl, M.T., Vauras, J. \& Hibbett, D.S. (2007) Contributions of rpb2 and tefl to the phylogeny of mushrooms and allies (Basidiomycota, Fungi). Molecular Phylogenetics and Evolution 43 (2): 430-451. http://dx.doi.org/10.1016/j.ympev.2006.08.024

Moncalvo, J.M., Vilgalys, R., Redhead, S.A., Johnson, J.E., James, T.Y., Aime, M.C., Hofstetter, V., Verduin, S.J.W., Larsson, E., Baroni, T.J., Thorn, R.G., Jacobsson, S., Clémen?on, H. \& Miller Jr, O.K. (2002) One hundred and seventeen clades of euagarics. Molecular Phylogenetics and Evolution 23 (3): 357-400. http://dx.doi.org/10.1016/s1055-7903(02)00027-1

Mortimer, P.E., Karunarathna, S.C., Li, Q.H., Gui, H., Yang, X.Q., Yang, X.F., He, J., Ye, L., Guo, J.Y., Li, H.L., Sysouphanthong, P., Zhou, D.Q., Xu, J.C. \& Hyde, K.D. (2012) Prized edible Asian mushrooms: ecology, conservation and sustainability. Fungal Diversity 56 (1): 31-47.

Noordeloos, M.E. (1999) Genus Psilocybe. In: Bas, C., Kuyper, T.W., Noordeloos, M.E., Vellinga, E.C. (Eds.), Flora agaricina neerlandica, vol. 4. A.A.Balkema, Brookfield, Rotterdam, pp. 27-79.

Noordeloos, M.E. (2011) Strophariaceae s.l. Fungi Europaei Vol. 13. Edizione Candusso, Alassio, Italy, 648 pp.

Norvell, L.L. (2009) Report of the Nomenclature Committee for Fungi: 15. Mycotaxon 110: 487-492. http://dx.doi.org/10.5248/110.487 
Nugent, K.G. \& Saville, B.J. (2004) Forensic analysis of hallucinogenic fungi: a DNA-based approach. Forensic Science International 140: 147-157.

http://dx.doi.org/10.1016/j.forsciint.2003.11.022

Page, R.D.M. (1996) TreeView: an application to display phylogenetic trees on personal computers. Computer Applications in the Biosciences 12 (4): 357-358.

Pornpakakul, S., Suwancharoen, S., Petsom, A., Roengsumran, S., Muangsin, N., Chaichit, N., Piapukiew, J., Sihanonth, P. \& Allen, J.W. (2009) A new sesquiterpenoid metabolite from Psilocybe samuiensis. Journal of Asian Natural Products Research 11 (1): 12-17. http://dx.doi.org/10.1080/10286020802435794

Posada, D. \& Crandall, K.A. (1998) MODELTEST: testing the model of DNA substitution. Bioinformatics 14 (9): $817-818$. http://dx.doi.org/10.1093/bioinformatics/14.9.817

Ramírez-Cruz, V., Guzmán, G., Villalobos-Arámbula, A.R., Rodríguez, A, Matheny, P.B., Sánchez-García, M. \& GuzmánDávalos, L. (2013) Phylogenetic inference and trait evolution of the psychedelic mushroom genus Psilocybe sensu lato (Agaricales). Botany 91 (9): 573-591. http://dx.doi.org/10.1139/cjb-2013-0070

Redhead, S.A., Moncalvo, J.M., Vilgalys, R., Matheny, P.B., Guzmán-Dávalos, L. \& Guzmán, G. (2007) Proposal to conserve the name Psilocybe (Basidiomycota) with a conserved type. Taxon 56(1): 255-257. http://dx.doi.org/10.2307/25065706

Ricken, A. (1915) Die Blätterpilze (Agaricaceae). Theodor Oswald Weigel, Leipzig, 480 pp.

Ridgway, R. (1912) Color standards and color nomenclature. Ridgway, Washington, D. C., 43 pp + 53 pl. http://dx.doi.org/10.5962/bhl.title.62375

Saccardo, P.A.(1887) Sylloge fungorum ominum hucusque cognitorum?. Padova, 1146pp.

Singer, R. (1948) Diagnoses fungorum novorum Agaricalium. Sydowia 2 (1-6): 26-42.

Singer, R. (1961) Diagnoses fungorum novorum Agaricalium II. Sydowia 15 (1-6):45-83.

Singer, R. (1986) The Agaricales in modern taxonomy. 4th. Koeltz Scientific Books, Koenigstein, 981 pp.

Singer, R. \& Smith, A.H. (1958) New species of Psilocybe. Mycologia 50 (1): 141-142. http://dx.doi.org/10.2307/3756045

Singer, R. \& Smith, A.H. (1958) Mycological investigations on teonanácatl, the Mexican hallucinogenic mushroom. Part II. A taxonomic monograph of Psilocybe, section Caerulescentes. Mycologia 50: 262-303. http://dx.doi.org/10.2307/3756197

Smith, A.H.(1937) New and unusual Agarics from the western United States. Mycologia 29 (1): 45-59. http://dx.doi.org/10.2307/3754199

Stamets, P. (1996) Psilocybin mushrooms of the world. Ten Speed Press, Berkeley, USA, 245 pp.

Swofford, D.L. (2002) PAUP*: Phylogenetic analysis using parsimony (*and other methods), Version 4.0b10. Sinauer Associates, Sunderland.

Tai, F.L. (1979) Sylloge Fungorum Sinicorum. Science Press, Beijing, 1527pp.

Teng, S.C. (1963) Fungi of China. Science Press, Beijing, 808 pp.

Thomas, K.A., Manimohan, P., Guzmán, G., Tapia, F. \& Ramírez-Guillén, F. (2002) The genus Psilocybe in Kerala State, India. Mycotaxon 83: 195-207.

Thompson, J.D., Gibson, T.J., Plewniak, F., Jeanmougin, F. \& Higgins, D.G. (1997) The CLUSTAL_X windows interface: flexible strategies for multiple sequence alignment aided by quality analysis tools. Nucleic Acids Research 25 (24): 48764882. http://dx.doi.org/10.1093/nar/25.24.4876

Walther, G., Garnica, S. \& Weiß, M. (2005) The systematic relevance of conidiogenesis modes in the gilled Agaricales. Mycological Research 109 (5): 525-544. http://dx.doi.org/10.1017/s0953756205002868

Wang, X.H., Liu, P.G. \& Yu, F.Q. (2004) Color atlas of wild commercial mushrooms in Yunnan. Yunnan Science and Technology Press, Kunming, 136 pp.

Watling, R. \& Martín, M.P. (2003) A sequestrate Psilocybe from Scotland. Botanical Journal of Scotland 55(2): $245-257$. http://dx.doi.org/10.1080/03746600308685009

White, T.J., Bruns, T., Lee, S. \& Taylor, J.W. (1990) Amplification and direct sequencing of fungal ribosomal RNA genes for phylogenies. In: Innis, M.A., Gelfand, D.H., Sninsky, J.J., White, T.J. (Eds.), PCR protocols: a guide to methods and applications. Academic Press, New York, pp. 315-322.

Yang, Z.L. (2002) On wild mushroom resources and their utilization in Yunnan Province, Southwest China. Journal of Natural Rresources 4 (17): 463-469.

Yang, Z.L. (2005) Diversity and biogeography of higher fungi in China. In: Xu, J.P. (Ed.), Evolutionary genetics of fungi. Horizon Bioscience, Norfolk (UK), pp. 35-62.

Yang, Z.L. (2009) Recent studies on species diversity of higher fungi in the mountains of southwest China. Fungal Science 24: 255-263.

Yang, Z.L. (2010) Inventory of higher fungi in the Hengduan Mountains of southwestern China. Chinese Bulletin of Life Sciences 22 (11): 1086-1091. 
Yang, Z.L., Matheny, P.B., Ge, Z.W., Slot, J.C. \& Hibbett, D.S. (2005) New Asian species of the genus Anamika (euagarics, hebelomatoid clade) based on morphology and ribosomal DNA sequences. Mycological Research 109 (11): $1259-1267$. http://dx.doi.org/10.1017/s0953756205003758

Yang, Z.L., Weiß, M. \& Oberwinkler, F. (2004) New species of Amanita from the eastern Himalaya and adjacent regions. Mycologia 96 (3): 636-646.

http://dx.doi.org/10.2307/3762180

Yokoyama, T. (1976) A new hallucinogenic mushroom, Psilocybe argentipes K. Yokoyama sp. nov. from Japan. Transactions of the Mycological Society of Japan 17: 349-354.

Yuan, M.S. \& Sun, P.Q. (2007) The Pictorial Book of Mushroom of China. Sichuan Science and Technology Press, Chengdu, $552 \mathrm{pp}$.

Zeng, N.K., Tang, L.P., Li, Y.C., Tolgor, B., Zhu, X.T., Zhao, Q. \& Yang, Z.L. (2013) The genus Phylloporus (Boletaceae, Boletales) from China: morphological and multilocus DNA sequence analyses. Fungal Diversity 58 (1): 73-101. http://dx.doi.org/10.1007/s13225-012-0184-7 